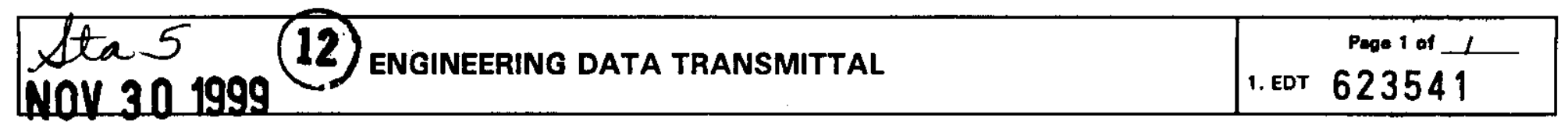

\begin{tabular}{|l|l|}
\hline $\begin{array}{l}\text { 2. To: (Receiving Organization) } \\
\text { Distribution }\end{array}$ & $\begin{array}{l}\text { 3. From: (Originating Organization) } \\
\text { WRAP Engineering }\end{array}$ \\
\hline $\begin{array}{l}\text { 5. Proj./Prog./Dept./Div.: } \\
\text { WRAP/AJ60 }\end{array}$ & $\begin{array}{l}\text { 6. Design Authority/Design Agent/Cog. Engr.: } \\
\text { MD Johnson }\end{array}$ \\
\hline
\end{tabular}

\section{Originator Remarks:}

This EDT is to release supporting documentation for the WRAP

Facility to Engineering Files for retention and retrieval.

11. Receiver Remarks:

11A. Design Baseline Document? $O$ Yes

O No

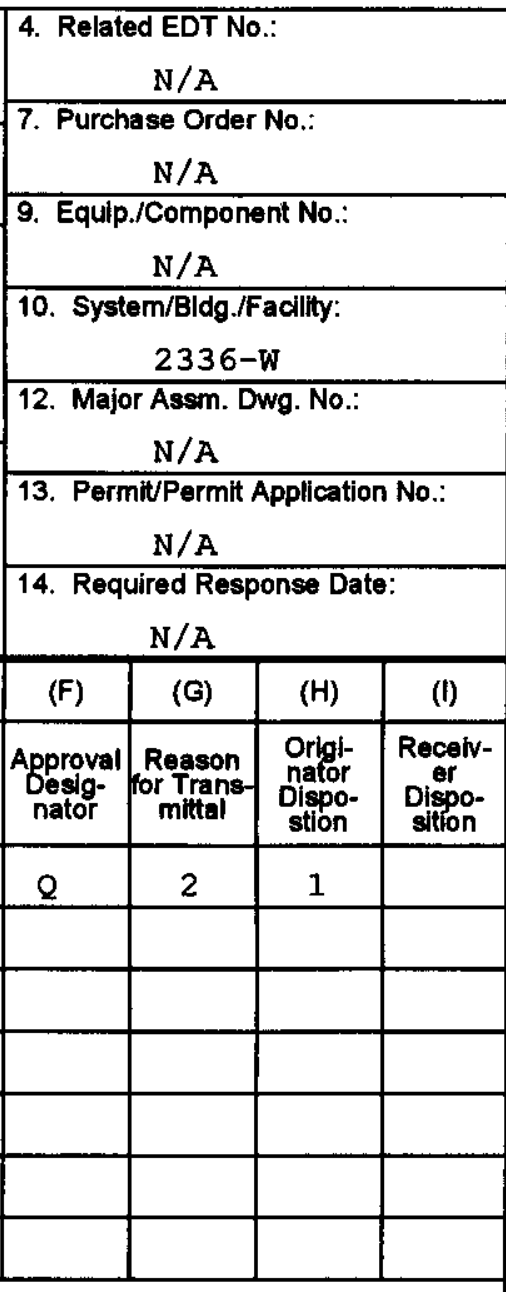

(E) Title or Description of Data Transmitted
16.

\begin{tabular}{|c|c|}
\hline Approval Designator (F) & \\
\hline $\begin{array}{c}\text { E, S, Q, D OR N/A } \\
\text { (See'WHC-CM-3-5, } \\
\text { Sec. 12.7) }\end{array}$ & $\begin{array}{l}\text { 1. Approval } \\
\text { 2. Release } \\
\text { 3. Information }\end{array}$ \\
\hline
\end{tabular}

17.

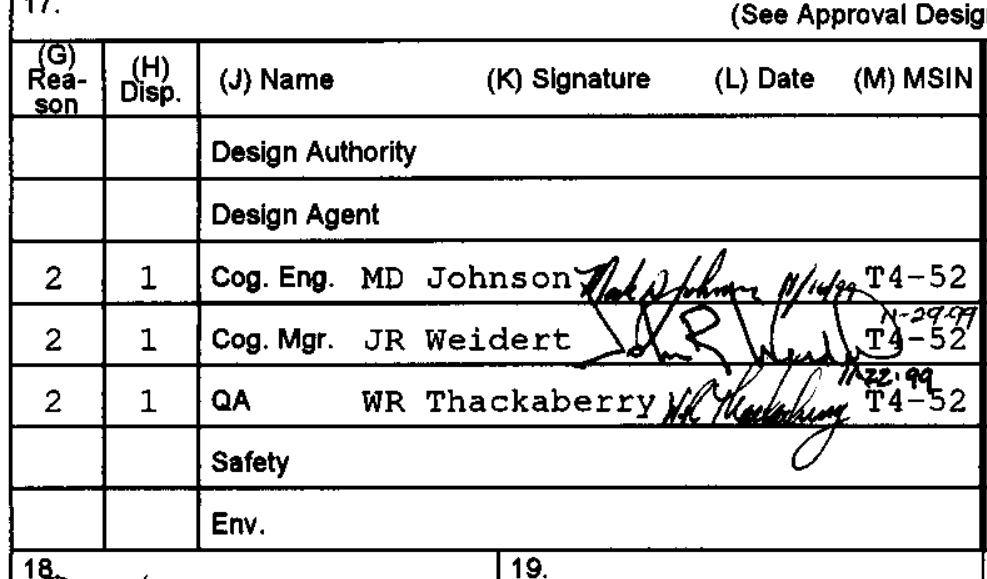

18.

HK Kerstex

JK Kersten

Signature of EDT

originator
Reason for Transmittal (G)

4. Review

6. Dist. (Receipt Acknow. Required) $\frac{11-29-99}{\text { Date }}$

Authorized Representative for Receiving Organization

\section{DATA TRANSMITTED}

\begin{tabular}{|l|l|l}
$\begin{array}{l}\text { (C) Sheet } \\
\text { No. }\end{array}$ & $\begin{array}{l}\text { (D) Rev. } \\
\text { No. }\end{array}$ \\
\hline N/A & 0 & \\
\hline
\end{tabular}

\begin{tabular}{|ll|}
\hline \multicolumn{2}{|c|}{ Disposition (H) \& (I) } \\
$\begin{array}{ll}\text { 1. Approved } & \text { 4. Reviewed no/comment } \\
\text { 2. Approved w/comment } & \text { 5. Reviewed w/comment } \\
\text { 3. Disapproved w/comment } & \text { 6. Receipt acknowledged }\end{array}$ \\
\hline
\end{tabular}

3. Disapproved w/comment

6. Receipt acknowledged
KEY Weight Scale Analysis

SIGNATURE/DISTRIBUTION

(See Approval Designator for required signatures)

\begin{tabular}{|c|c|c}
\hline Rea- & (H) & (J) Name
\end{tabular}

(K) Signature

(L) Date

(M) MSIN

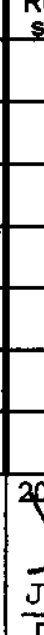

Date

JR Weidert
Design Authority/

Cognizant Manager

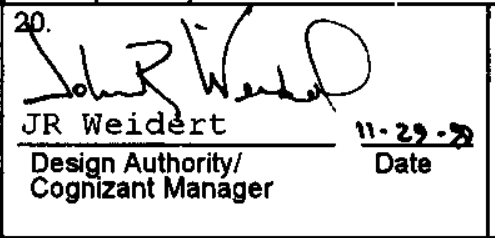

21. DOE APPROVAL (if required)

Ctrl No.

Approved

Approved w/comments

Disapproved w/comments 


\title{
Waste Receiving And Processing Facility Weight Scale Analysis Fairbanks Weight Scale Evaluation Results
}

\author{
MD Johnson \\ Waste Management Federal Services of Hanford, Inc., Richland, WA 99352 \\ U.S. Department of Energy Contract DE-AC06-96RL13200
EDT/ECN: EDT-623541 UC: 506
Org Code: 32600 Charge Code: AJ60 \\ B\&R Code: EW02J16 Total Pages: 14 \\ Key Words: WRAP, Infeed, Discharge Conveyor, Calibration, TRU, WIPP \\ Abstract: This document outlines the investigation of the infeed \\ conveyor scale failure and recommendations for calibration \\ procedure modifications.
}

** Digital Indicator Model H90-5200 and Fairbanks Weight Scales are registered trademarks of Fairbanks Scales, Inc., Kansas City, MO.

TRADEMARK DISCLAIMER. Reference herein to any specific commercial product, process, or service by trade name, tradenark, manufacturer, or otherwise, does not necessarily constitute or imply its endorsement, recormendation, or favoring by the United States Government or any agency thereof or its contractors or subcontractors.

Printed in the United States of America. To obtain copies of this document contact: Document Control Services, P.O. Box 950, Mailstop H6-08, Richland WA 99352, Phone (509) 372-2420;

Fax (509) 376-4989.
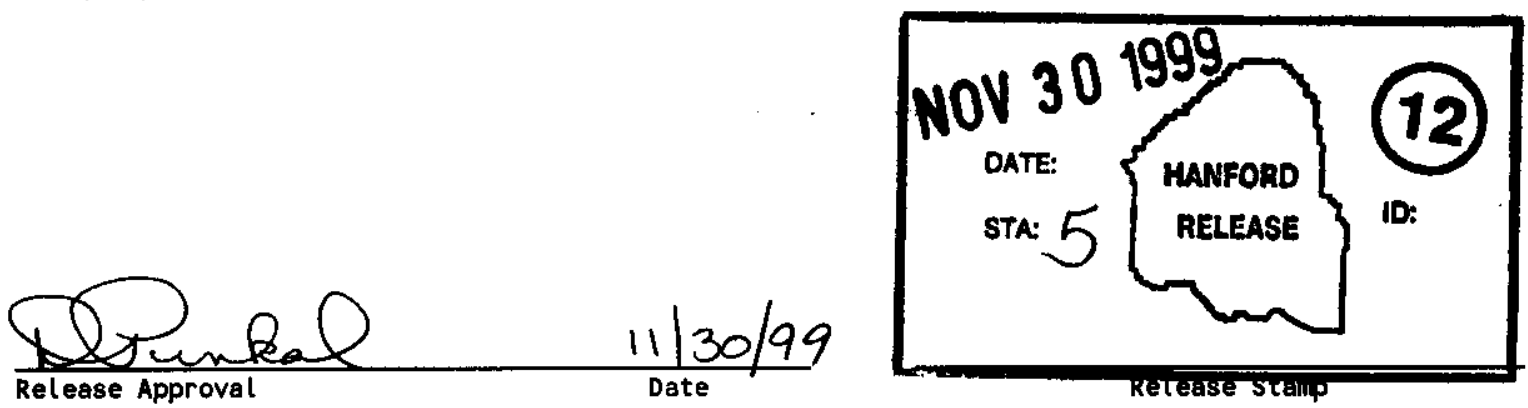

\section{Approved for Public Release}


Waste Receiving and Processing Facility

\section{Weight Scale Analysis}

Fairbanks Weight Scale Evaluation Results 
HNF-5408 Rev.0

\section{TECHNICAL ABSTRACT}

Fairbanks Weight Scales are used at the Waste Receiving and Processing (WRAP) facility to determine the weight of waste drums as they are received, processed, and shipped. Due to recent problems, discovered during calibration, the WRAP Engineering Department has completed this document which outlines both the investigation of the infeed conveyor scale failure in September of 1999 and recommendations for calibration procedure modifications designed to correct deficiencies in the current procedures. 
HNF-5408 Rev.0

TABLE OF CONTENTS

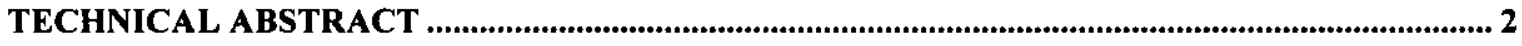

PART 1-CALIBRATION FAILURE (OVERVIEW) FOR THE INFEED CONVEYOR SCALE ...... 4

PART 2-EVALUATION OF THE WRAP CALIBRATION PROCEDURE SET-UP PERAMETERS

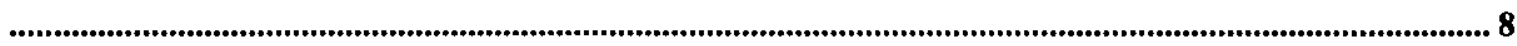

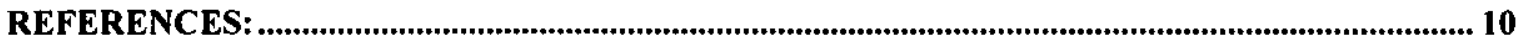

ATTACHMENTS

- TEST WEIGHT ANALYSIS SPEAD SHEET ..........................................A 


\section{PART 1}

\section{PART 1-CALIBRATION FAILURE (OVERVIEW) FOR THE INFEED CONVEYOR SCALE}

On September 9, 1999, an annual calibration procedure was performed on the infeed conveyor scale (101CV-05-103A) at the WRAP Facility shipping and receiving area. Performance of that procedure indicated that the "as found" scale response was outside specified calibration tolerances. Drum measurement data analysis indicated that measurements taken for drums weighing between $113.4 \mathrm{~kg}$ and $453.6 \mathrm{~kg}$ should be questioned. 15 of the 379 drums measured during the previous year fell into this category. Statistical analysis shows that 14 of the drums have the potential to be over tolerance by as much as $3.436 \mathrm{lbs}$. or under tolerance by as much as $1.806 \mathrm{lbs}$.. The measurement for the remaining drum has the potential of being over tolerance by as much as $13.89 \mathrm{lbs}$. or under tolerance by as much as $10.15 \mathrm{lbs}$. The Engineering Department recommends re-calculation of drum data to correct for the identified error. Calculation results must be evaluated to ensure that the assigned TRU/LLW classification of each drum is accurate.

\section{Background:}

During performance of the calibration procedure the scale response was verified using three (known value) test weights; $250 \mathrm{lbs}$. (113.4 kg), $500 \mathrm{lbs}$. $(226.8 \mathrm{~kg})$, and $1000 \mathrm{lbs}$. $(453.6 \mathrm{~kg})$. The scale was found within calibration at the $250 \mathrm{lb}$. (113.4 kg) level and out of calibration at the $500 \mathrm{lb}$. $(226.8 \mathrm{~kg})$ and $1000 \mathrm{lb}$. $(453.6 \mathrm{~kg})$ levels, as shown below:

Test Weight:

$250 \mathrm{lbs} . / 113.4 \mathrm{~kg}$

$500 \mathrm{lbs} . / 226.8 \mathrm{~kg}$

$1000 \mathrm{lbs} . / 453.6 \mathrm{~kg}$
As found :

$249.6 / 113.2 \quad$ lbs. $/ \mathrm{kg}$

$501.1 / 227.3$ lbs. $/ \mathrm{kg}$

$1002.9 / 454.9 \mathrm{lbs} . / \mathrm{kg}$
Tolerance $( \pm 0.1 \%$ full scale):

(249 to $251 \mathrm{lbs}$.)

(499 to $501 \mathrm{lbs}$.)

(999 to $1001 \mathrm{lbs}$.)

Immediate actions:

The scale was taken out of service and evaluated to determine the problem. An unbalance condition was discovered on the scale load cells. The load cell mounting hardware was shimmed to correct the problem and the unit was re-calibrated. 
Follow up actions:

The scale is calibrated on an annual basis. All Waste Container Data Sheets generated the previous year were reviewed to determine the impact on waste drum measurements. Each data sheet includes a "test weight" measurement to ensure that the scale is properly calibrated prior to operations. The test weight is either a $113.4 \mathrm{~kg}$ or a $22.68 \mathrm{~kg}$ weight and varies from day to day. All test weight measurements taken during operations were within calibration at both the $113.4 \mathrm{~kg}$ and $22.68 \mathrm{~kg}$ levels, likewise the scale checked within calibration at the $113.4 \mathrm{~kg}$ level during the calibration procedure. The scale calibration becomes questionable only at higher weights. Only 15 of the 379 drums measured between September 30 , 1998 and September 9, 1999, weighed $113.4 \mathrm{~kg}$ or more. The following are the container ID \#s for the 15 drums measuring over $113.4 \mathrm{~kg}$ :

\begin{tabular}{|c|l|l|}
\hline$\#$ & \multicolumn{1}{|c|}{ DRUM PIN } & \multicolumn{1}{c|}{ WEIGHT } \\
\hline 1 & 9601879 & 116.15 \\
\hline 2 & 9513558 & 117.25 \\
\hline 3 & 9522295 & 127.2 \\
\hline 4 & 9522503 & 200.25 \\
\hline 5 & 9406635 & 144.55 \\
\hline 6 & $9700807^{*}$ & 282.05 \\
\hline 7 & 9601581 & 116.9 \\
\hline 8 & 996000008 & 202.4 \\
\hline 9 & 996000009 & 205.1 \\
\hline 10 & 9406601 & 163.3 \\
\hline 11 & 9406618 & 141.65 \\
\hline 12 & 9513608 & 117 \\
\hline 13 & 9517481 & 132.4 \\
\hline 14 & 9517461 & 135 \\
\hline 15 & 9401105 & 150.3 \\
\hline
\end{tabular}

* indicates drum that also measure over $226.8 \mathrm{~kg}$ 
Statistical Analysis:

The test weight data from the Waste Container Data Sheets was used to determine typical scale response. Using that response data an estimate of scale accuracy has been formulated for the drums weighing over $113.4 \mathrm{~kg}$. A $95 \%$ confidence interval for the scale response was calculated using the test weight data. This data along with the "as-found" calibration test weight data allows us to determine a maximum upper and lower error interval for the measured drums. The error intervals at $226.8 \mathrm{~kg}$ (500lbs.) and $453.6 \mathrm{~kg}$ (1000 lbs.) are large due to the limited amount of measurement data available at these ranges.

\begin{tabular}{|c|c|c|c|c|}
\hline \multicolumn{5}{|c|}{$95 \%$ Confidence Interval for Drums Weighing $0-50 \mathrm{lbs} .(0-22.68 \mathrm{~kg})$} \\
\hline Test weight & Mean Error & Uncertainty $95 \%$ & Lower Error Range & Upper Error Range \\
\hline $22.68 \mathrm{~kg}$ & -0.1504 & $-0.1504 \pm .03965 \mathrm{~kg}$ & $-0.419 \mathrm{lbs} . /-0.19 \mathrm{~kg}$ & $-0.2441 \mathrm{lbs} /-0.11 \mathrm{~kg}$ \\
\hline \multicolumn{5}{|c|}{$95 \%$ Confidence Interval for Drums Weighing $50-250 \mathrm{lbs} .(22.68-113.4 \mathrm{~kg})$} \\
\hline Test weight & Mean Error & Uncertainty $\mathbf{9 5 \%}$ & Lower Error Range & Upper Error Range \\
\hline $113.4 \mathrm{~kg}$ & -0.2339 & $-0.233 \pm .0592 \mathrm{~kg}$ & $-0.505 \mathrm{lbs} /-0.229 \mathrm{~kg}$ & $-0.383 \mathrm{lbs} . /-0.174 \mathrm{~kg}$ \\
\hline \multicolumn{5}{|c|}{$95 \%$ Confidence Interval for Drums Weighing $250-500$ lbs. (113.4-226.8 kg) } \\
\hline Test weight & Mean Error & Uncertainty $\mathbf{9 5 \%}$ & Lower Error Range & Upper Error Range \\
\hline $500 \mathrm{lb}$. & 0.815 & $0.815 \pm 3.621 \mathrm{lbs}$ & $-2.806 \mathrm{lbs} . /-1.273 \mathrm{~kg}$ & $4.436 \mathrm{lbs} . / 2.012 \mathrm{~kg}$ \\
\hline \multicolumn{5}{|c|}{$95 \%$ Confidence Interval for Drums Weighing 500-1000 lbs. (226.8-453.6 kg) } \\
\hline Test weight & Mean Error & Uncertainty $95 \%$ & Lower Error Range & Upper Error Range \\
\hline $1000 \mathrm{lb}$. & 1.875 & $1.875 \pm 13.024 \mathrm{lbs}$ & $-11.149 \mathrm{lbs} . /-5.057 \mathrm{~kg}$ & $14.899 \mathrm{lbs} / 6.758 \mathrm{~kg}$ \\
\hline
\end{tabular}

(Table 2)

Conclusions:

Of the 15 drums that measured over $113.4 \mathrm{~kg}$, only 1 measured over $226.8 \mathrm{~kg}$. Therefore, 14 drums may be over tolerance by $3.436 \mathrm{lbs}$. or under tolerance by $1.806 \mathrm{lbs}$.. The remaining drum may be over tolerance by up to $13.90 \mathrm{lbs}$. or under tolerance by $10.15 \mathrm{lbs}$.

Recommendations:

1. The Engineering Department recommends re-calculation of the drum data for the drums listed in Table 1 . The calculation results must be reviewed for impact on TRU/LLW drum classification.

2. The weight scale calibration should be performed at a higher frequency on the WIPP impacting scales (i.e. quarterly rather than annually) to reduce programmatic impacts should scales be found out of calibration in the future. 
3. During evaluation of the scale, information regarding scale set-up parameters and scale performance was discovered that suggests re-evaluation of set up criteria and tolerance limits is needed. The Engineering Department performed a follow up evaluation for scale set-up and calibration. The results of that evaluation are outlined in part 2 of this document.

4. Following the scale set-up and calibration evaluation, both infeed and discharge scales will require recalibration to implement the recommendations of the evaluation.

5. In the future, control charts should be maintained on the test/check weight measurements taken prior to daily operation. This tool will help us recognize scale response problems early, before they significantly impact operations data. 
HNF-5408 Rev.0

\section{PART 2}

\section{PART 2-EVALUATION OF THE WRAP CALIBRATION PROCEDURE SET-UP PERAMETERS}

This section serves as a follow up to PART 1 of this document performed on the infeed conveyor scale (101-CV-05-103A) at the Waste Receiving And Processing (WRAP) facility shipping and receiving area. Recommendation \# 3 of PART 1 was to re-evaluate the set-up parameters for the infeed conveyor drum scale used to measure Waste Isolation Pilot Project (WIPP) related containers at the WRAP facility. This document outlines the Engineering Departments recommendations for changes to the scale settings at the WRAP facility and explains the reasoning behind those recommendations.

\section{Background:}

The Fairbanks weight scales used at WRAP are designed to operate in either one of two modes: general use mode (security level 0 ); or, commercial rated mode (Security levels $1 \& 2$ ). The scales operate by dividing their maximum capacity weight rating by the desired graduation size to determine the number of divisions required to calibrate the scale, it then assigns a number of digital counts to each division. In security level 0 that number of counts is 1 per division, in security levels $1 \& 2$ that number is 3 counts per division. In security levels $1 \& 2$ the scale uses the three counts to verify the measurement is at the weight indicated on the display, in security level 0 the scale uses only one count to measure the weight and does not verify the measurement. The scales have only a limited number of counts available when calibrating (36000 total); so, selection of the higher security levels ( 1 or 2) limits the graduation resolution available ( i.e. in security level 0 the scale might allow a graduation size of $.05 \mathrm{~kg}$ but in security level $1 \& 2$ the scale will only allow a graduation size of $.1 \mathrm{~kg}$ ). Another feature of the security level selection is a password protect function. When in security level lor 2 the scales "set-up" parameters are protected by a control panel password, preventing unauthorized changes to the calibration of the scale. In security level 0 no password protection is provided and the scale parameters may be changed from the control panel by any user. 
Issues:

It was previously believed that the scales at WRAP were calibrated in the commercial mode because security level 2 was selected in the scale set-up sequence as one of the final steps of the calibration procedure, this belief was in error. The security level must be selected before calibrating the scale in order to establish the commercial or general use mode. While changing the security level switch after calibration did provide password protection, the scale measurement function was still operating in the general use mode. During re-calibration efforts for the infeed conveyor scale, following the out of calibration condition found on September 9,1999, it was discovered that the scale was actually functioning in the general use mode rather than the commercial rated mode as was previously believed. After corrective maintenance on a loose load cell mounting pin the scale was re-calibrated in the commercial mode. This required that the graduation size of the scale be increased from $0.1 \mathrm{lbs} .(0.05 \mathrm{~kg})$ to $0.5 \mathrm{lbs} .(0.2 \mathrm{~kg})$ do to the limited number of counts available in commercial mode. The scale was tested and returned to service. This new set-up configuration may create problems during future calibration attempts as the scales graduation size is now $0.5 \mathrm{lbs}$. and the tolerance range for the scale is only $\pm 1.0 \mathrm{lb}$.. An error of only 3 graduations will now result in an out of tolerance condition and observed error (as the scale returns to zero) has often been $\pm 1.0 \mathrm{lb}$. leaving no error tolerance for the actual measurement.

Recommendations:

1. The Engineering Department recommends re-calibrating all WRAP scales in the general use mode (security level 0$)$ to allow the uses of a smaller $(.05 \mathrm{~kg})$ graduation size. Test data shows that scale repeatability is excellent even when in the general use mode and selecting the smaller graduation size results in less "return to zero" error on the scales. After the re-calibration of the scales the security level can be returned to the level 2 setting to password protect the settings. The WRAP Authorization Basis documents take no credit for a commercial rating on these scales; so, no changes are needed to the current facility documents.

2. The current calibration procedure for the infeed scale lists an acceptance tolerance of $\pm 1.0 \mathrm{lb}$. for all measurements, this tolerance is calculated by taking $0.1 \%$ of the full scale reading (based on a scale capacity of $1000 \mathrm{lbs}$.). The actual scale capacity for the infeed conveyor scale is approximately 2200 $2400 \mathrm{lbs}$. and although WRAP has no plans to weigh drums over $1000 \mathrm{lbs}$. the scale tolerance must be calculated using the actual capacity of the scale not on the maximum expected weight of a drum at the WRAP facility. The existing tolerance of $\pm 1.0 \mathrm{lb}$. is not realistic for this scale and should be reestablished based on the actual rating of the scale. The Engineering Department recommends using $1000 \mathrm{~kg}(2204.6 \mathrm{lbs}$.) as the scale's maximum capacity when calculating the tolerance for future calibration procedures. This will result in a tolerance of $\pm 1.0 \mathrm{~kg}$ (or $2.2 \mathrm{lbs}$.) for each measurement. This recommendation also applies to the discharge conveyor scale and the calibration procedures for both should be revised to incorporate the new tolerance.

3. Lift table scales in the process area are not needed for WIPP certification of drums and the primary function of the scales is to measure drum pressure against the bottom of the glove box ports. It is not necessary for these scales to be as accurate as the WIPP certification scales. Present calibration procedures require that lift table scales be calibrated to the same tolerance as the infeed and discharge conveyor scales, this practice is not necessary and may result in costly corrective maintenance to bring the scales into tolerance. The Engineering Department recommends relaxing the tolerance on these scales to $\pm 1.0 \%$ or $\pm 10 \mathrm{~kg}$ ( $22.04 \mathrm{lbs}$.).

4. The Engineering Department also recommends reducing the number of WIPP related scales at WRAP. Only the infeed conveyor, discharge conveyor, and NDE box scales are needed for WIPP certification at WRAP. Calibration of airlock scales is not necessary. As a cost saving measure the Engineering Department recommends discontinuing calibration of the airlock scales. 
5. During present calibration of the scales only one "as left" measurement (with each test weight) is recorded to establish calibration of each scale. The Engineering Department recommends increasing the number of "as left" measurements to verify repeatability of the measurements and to provide additional measurement sample data for problem analysis in the future.

6. Additional check weight measurements are recommended (at higher weight values) to help determine scale response. A $453.6 \mathrm{~kg}(1000 \mathrm{lb}$.) and $226.8 \mathrm{~kg}(500 \mathrm{lb}$.) periodic check weight measurement would provide the data needed (i.e. measurements may be taken only on days when heavy drums are processed).

7. The Engineering Department recommends that scale calibration procedure WRP-18004 be revised and that the recommendations listed in this evaluation be incorporated.

\section{REFERENCES:}

Fairbanks Scales Service Manual, Digital Indicator Model H90-5200 


\section{Analysis Of $113.4 \mathrm{~kg}$ Test Weight Data (Rev 2)}

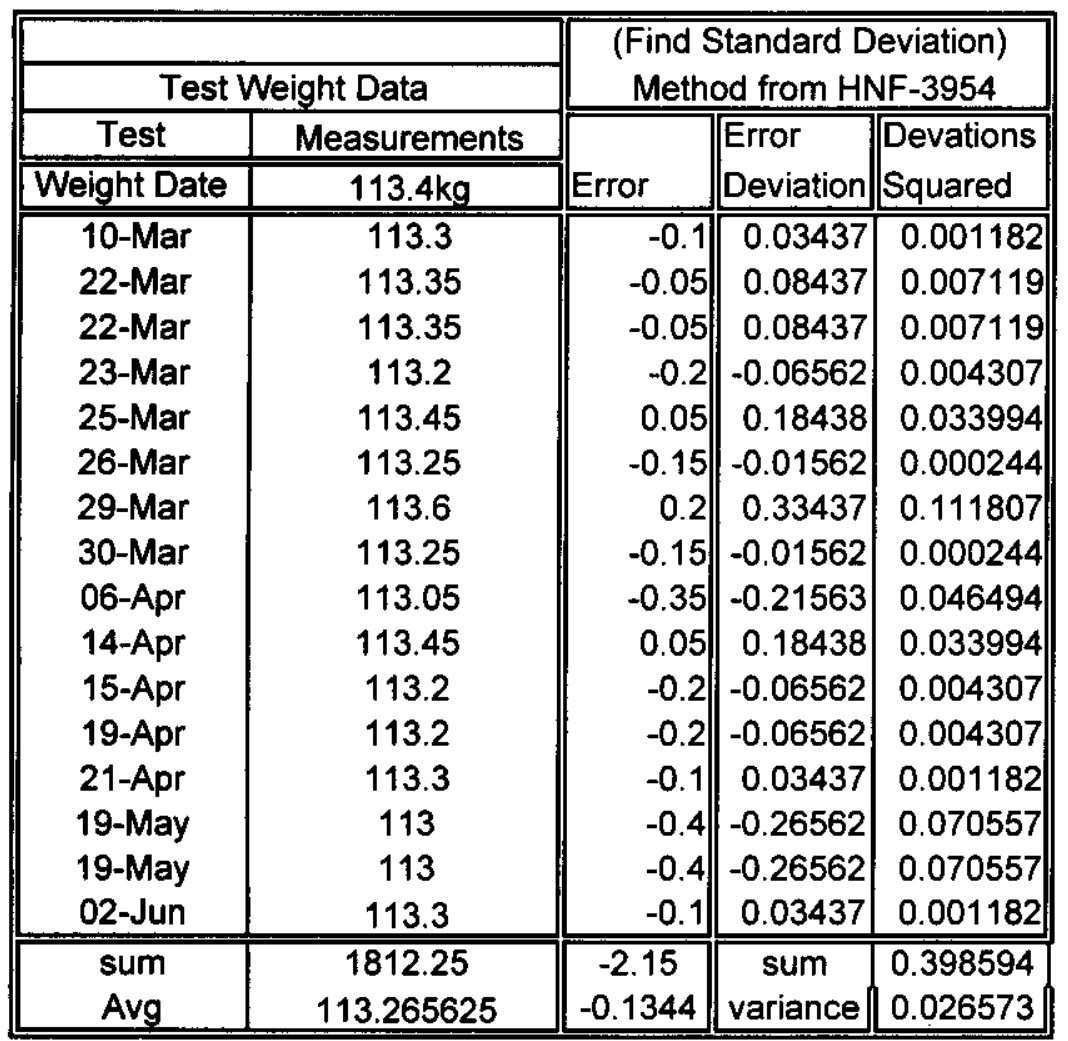

\begin{tabular}{||lr||}
\hline \multicolumn{2}{|c|}{ Statistical Analysis } \\
\hline Mean & 113.2656 \\
Standard Error & 0.040753 \\
Median & 113.275 \\
Mode & 113.3 \\
Standard Deviation & 0.163012 \\
Sample Variance & 0.026573 \\
Kurtosis & 0.113816 \\
Skewness & 0.050654 \\
Range & 0.6 \\
Minimum & 113 \\
Maximum & 113.6 \\
Sum & 1812.25 \\
Count & 16 \\
Largest(1) & 113.6 \\
Smallest(1) & 113 \\
Confidence Level(95.0\%) & 0.086863 \\
\hline
\end{tabular}

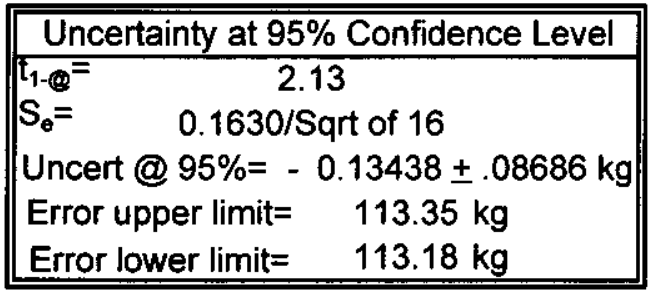

Analysis Of $22.68 \mathrm{~kg}$ Test Weight Data (Rev2)

\begin{tabular}{|c|c|c|c|c|}
\hline Test & ight Data & \multicolumn{3}{|c|}{$\begin{array}{c}\text { (Find Standard Deviation) } \\
\text { Method from HNF-3954 }\end{array}$} \\
\hline Test & Measurements & & Error & |Devations \\
\hline Weight Date & 22.68 & Error & Deviation & Squared \\
\hline 13-Apr & 22.5 & -0.18 & -0.02963 & 0.000878 \\
\hline 20-Apr & 22.6 & -0.08 & 0.07037 & 0.004952 \\
\hline 25-May & 22.6 & -0.08 & 0.07037 & 0.004952 \\
\hline 30-Jun & 22.55 & -0.13 & 0.02037 & 0.000415 \\
\hline 01-Jul & 22.4 & -0.28 & -0.12963 & 0.016804 \\
\hline 02-Jul & 22.4 & -0.28 & -0.12963 & 0.016804 \\
\hline 06-Jul & 22.65 & -0.03 & 0.12037 & 0.014489 \\
\hline
\end{tabular}




\begin{tabular}{||c|c||r||r|r||} 
12-Jul & 22.6 & -0.08 & 0.07037 & 0.004952 \\
13-Jul & 22.45 & -0.23 & -0.07963 & 0.006341 \\
15-Jul & 22.45 & -0.23 & -0.07963 & 0.006341 \\
14-Jul & 22.65 & -0.03 & 0.12037 & 0.014489 \\
15-Jul & 22.45 & -0.23 & -0.07963 & 0.006341 \\
27-Jul & 22.65 & -0.03 & 0.12037 & 0.014489 \\
30-Jul & 22.5 & -0.18 & -0.02963 & 0.000878 \\
02-Aug & 22.4 & -0.28 & -0.12963 & 0.016804 \\
02-Aug & 22.4 & -0.28 & -0.12963 & 0.016804 \\
09-Aug & 22.65 & -0.03 & 0.12037 & 0.014489 \\
12-Aug & 22.5 & -0.18 & -0.02963 & 0.000878 \\
12-Aug & 22.45 & -0.23 & -0.07963 & 0.006341 \\
11-Aug & 22.6 & -0.08 & 0.07037 & 0.004952 \\
12-Aug & 22.5 & -0.18 & -0.02963 & 0.000878 \\
16-Aug & 22.65 & -0.03 & 0.12037 & 0.014489 \\
18-Aug & 22.6 & -0.08 & 0.07037 & 0.004952 \\
19-Aug & 22.3 & -0.38 & -0.22963 & 0.05273 \\
30-Aug & 22.6 & -0.08 & 0.07037 & 0.004952 \\
10-Sep & 22.6 & -0.08 & 0.07037 & 0.004952 \\
14-Sep & 22.6 & -0.08 & 0.07037 & 0.004952 \\
\hline \hline sum & 608.3 & -4.06 & sum & 0.261296 \\
Avg & 22.52962963 & -0.1504 & variance & 0.01005 \\
\hline
\end{tabular}

\begin{tabular}{||lr||}
\hline \multicolumn{2}{|c|}{ Statistical Analysis } \\
\hline Mean & 22.52963 \\
Standard Error & 0.019293 \\
Median & 22.55 \\
Mode & 22.6 \\
Standard Deviation & 0.100249 \\
Sample Variance & 0.01005 \\
Kurtosis & -0.827448 \\
Skewness & -0.471201 \\
Range & 0.35 \\
Minimum & 22.3 \\
Maximum & 22.65 \\
Sum & 608.3 \\
Count & 27 \\
Largest(1) & 22.65 \\
Smallest(1) & 22.3 \\
Confidence Level(95.0\%) & 0.039657 \\
\hline
\end{tabular}

\begin{tabular}{||lc||}
\hline \multicolumn{3}{|c||}{ Uncertainty at 95\% Confidence Level } \\
\hline $\mathrm{t}_{1-\Theta}=$ & 2.06 \\
$\mathrm{~S}_{\mathrm{o}}=$ & $0.100249 /$ Sqrt of 27 \\
Uncert @ 95\%= & $0.1504 \pm .03965 \mathrm{~kg}$ \\
Error upper limit= & $22.56 \mathrm{~kg}$ \\
Error lower limit $=$ & $22.49 \mathrm{~kg}$ \\
\hline
\end{tabular}


Analsis of Calibration Procedure Measurements at 500 LBS. (Rev2)

\begin{tabular}{||c|c|c|r|l|r||}
\hline Date & reading & Test wt & Error & $\begin{array}{l}\text { Error } \\
\text { Deviation }\end{array}$ & $\begin{array}{l}\text { Devation } \\
\text { Squared }\end{array}$ \\
\hline \hline 11-Aug-98 & 500.53 & 500 & 0.53 & -0.285 & 0.081225 \\
09-Aug-99 & 501.1 & 500 & 1.1 & 0.285 & 0.081225 \\
\hline & sum & 1.63 & sum & 0.16245 \\
Avg & 0.815 & Variance & 0.16245 \\
\hline
\end{tabular}

\begin{tabular}{||lc||}
\hline \multicolumn{2}{|c|}{ Statistical Analysis } \\
\hline Mean & 500.815 \\
Standard Error & 0.285 \\
Median & 500.815 \\
Mode & $\#$ N/A \\
Standard Deviation & 0.403051 \\
Sample Variance & 0.16245 \\
Kurtosis & $\#$ DIV/0! \\
Skewness & $\# D I V / 0 !$ \\
Range & 0.57 \\
Minimum & 500.53 \\
Maximum & 501.1 \\
Sum & 1001.63 \\
Count & 2 \\
Largest(1) & 501.1 \\
Smallest(1) & 500.53 \\
Confidence Level(95.0\%) & 3.621253 \\
\hline
\end{tabular}

\section{Analysis of Calibration Procedure Measurements at 1000 LBS. (Rev 2)}

\begin{tabular}{|c|c|c|r|l|r||}
\hline Date & reading & Test wt & Error & $\begin{array}{l}\text { Error } \\
\text { Deviation }\end{array}$ & $\begin{array}{l}\text { Devation } \\
\text { Squared }\end{array}$ \\
\hline \hline 11-Aug-98 & 1000.85 & 1000 & 0.85 & -1.025 & 1.050625 \\
09-Aug-99 & 1002.9 & 1000 & 2.9 & 1.025 & 1.050625 \\
\hline & sum & 3.75 & sum & 2.10125 \\
& Avg & 1.875 & Variance & 2.10125 \\
\hline
\end{tabular}

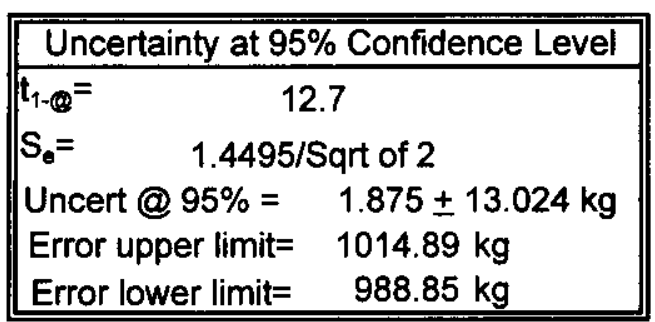

\begin{tabular}{||lc||}
\hline \multicolumn{2}{|c|}{ Statistical Analysis } \\
\hline & 1001.875 \\
Mean & 1.025 \\
Standard Error & 1001.875 \\
Median & $\#$ N/A \\
Mode & 1.449569 \\
Standard Deviation & 2.10125 \\
Sample Variance & \#IV/0! \\
Kurtosis & \#DIV/0! \\
Skewness & 2.05 \\
Range & 1000.85 \\
Minimum & 1002.9 \\
Maximum & 2003.75 \\
Sum & 2 \\
Count & 1002.9 \\
Largest(1) & 1000.85 \\
Smallest(1) & 13.0238 \\
Confidence Level(95.0\%) & \\
\hline
\end{tabular}

Page A3 
DISTRIBUTION SHEET

\begin{tabular}{|c|c|c|c|c|c|}
\hline \multirow{2}{*}{$\begin{array}{l}\text { To } \\
\text { Distribution }\end{array}$} & \multirow{2}{*}{\multicolumn{3}{|c|}{$\begin{array}{l}\text { From } \\
\text { WRAP Engineering }\end{array}$}} & \multicolumn{2}{|l|}{ Page 1 of 1} \\
\hline & & & & \multicolumn{2}{|c|}{ Date $11 / 17 / 99$} \\
\hline \multirow{2}{*}{\multicolumn{4}{|c|}{$\begin{array}{l}\text { Project Title/Work Order } \\
\text { WRAP WEIGHT SCALE ANALYSIS RESULTS }\end{array}$}} & \multicolumn{2}{|c|}{ EDT No. $N / A$} \\
\hline & & & & \multicolumn{2}{|c|}{ ECN No. EDT-623541 } \\
\hline Name & MSIN & $\begin{array}{c}\text { Text } \\
\text { With All } \\
\text { Attach. }\end{array}$ & Text Only & $\begin{array}{l}\text { Attach./ } \\
\text { Appendix } \\
\text { Only }\end{array}$ & $\begin{array}{l}\text { EDT/ECN } \\
\text { Only }\end{array}$ \\
\hline
\end{tabular}

EV DosRamos

JE Geary

WG Jason

MD Johnson

JK Kersten

MP Lane

$\mathrm{JL}$ Maupin

LW Roberts

CE Taylor

WR Thackaberry

JR Weidert

CE Wills

DOE/RL Reading Room

Engineering Files
T4-52

T4-51 X

T4-05 $X$

T4-52 $X$

T4-52 $X$

T4-52

$x$

T4-06 $X$

T4-51

$x$

T4-52

X

T4-52

T4-52

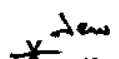

T4-52

$x$

H2-53

$x$

B1-07

$X$ $x$ 